\title{
Development and Optimization of Furrow Opener for Planting of Seed Spices
}

\author{
Mukesh Kumar Singh*, G. S. Tiwari, A. K. Mehta, Ajay Kumar Sharma, \\ S. M. Mathur and R. K. Rathod \\ Department of Farm Machinery and Power Engineering, College of Technology and \\ Engineering, MPUAT, Udaipur \\ *Corresponding author
}

\section{A B S T R A C T}

\section{Keywords}

Furrow opener, Seed spices, Draft, Furrow backfill

\section{Article Info}

\section{Accepted:}

15 April 2020

Available Online:

10 May 2020
Depth of sowing for seed spices are kept very shallow (1 to $3 \mathrm{~cm}$ ). Therefore, furrow openers commonly used in seed drills or planter are not very well suited for sowing of seed spices. Some of the spices seed e.g. cumin, coriander and fenugreek are highly sensitive to germination, if proper depth of sowing is not maintained. Even a small layer of soil over the seed affects the germination. Therefore furrow opener is very important component to ensure proper seed and soil contact as well as proper seed placement depth of these seed spices. The effects of three operating speeds $(1.5,2$ and $2.5 \mathrm{~km} / \mathrm{h})$, tip cutting thickness (2, 3.5 and $5 \mathrm{~mm})$, depth of operation $(15,25$ and $35 \mathrm{~mm})$ and tilt angle $\propto\left(3^{0}, 9^{0}\right.$ and $\left.13^{0}\right)$ on draft requirement and furrow back fill percentage were evaluated for optimization of furrow opener for the planting seeds of coriander, fenugreek and coriander. The optimized and predicted value of parameters matched with the F2 furrow opener on the basis of criteria set for optimization of furrow opener. The furrow opener F2 maintained better furrow backfill percentage.

\section{Introduction}

India is world's largest producer, consumer and exporter of seed spices. The seed spices viz., cumin, coriander and fenugreek accounts for about 36 per cent and 17 per cent of the total area and production, respectively of spices cultivation in the country. The seed spices possess industrial importance and are used in cosmetics, perfumery and pharmaceutical preparations. There are about 20 seed spices grown in India and the most important among them are coriander (Coriandrum sativum L.), cumin (Cuminum cyminum L.), fenugreek (Trigonella foenumgraecum, Trigonella corniculata L.) and Fennel (Foeniculum vulgare Mill.), which are cultivated conspicuously in larger area and hence, categorized as major group of seed spices(Bhatt, 2013).

Coriander and cumin covers nearly 80 per 
cent of the seed spice area and production (Singh and Solanki, 2015).Major seed spices growing area spread from arid to semi-arid regions covering large area of Rajasthan and Gujarat. Seed spices are mostly grown by marginal to sub-marginal farmers (Anonymous, 2007). Therefore, improving land productivity is an essential component to meet the present demand of these crops by small farm mechanization. Seed spices are usually grown in the mild, equable climate of Gujarat and Rajasthan in October November, where rich, well-drained, sandy, loamy soil and the sunny conducive environment are available. Seed spices are generally small seeds of non-uniform shape requiring very fine seedbed and shallow sowing depths.

The sowing of seed spices is mainly done through broadcasting method or lines are made by an iron or wooden hook at $25-30 \mathrm{~cm}$ distance in the small field plots, the seed is dropped manually by hand and covered with hand or by dragging of thorny bushes over the field (Bhatt, 2013). The seed rate is kept at $12-16 \mathrm{~kg} / \mathrm{ha}$ for cumin, $10-16 \mathrm{~kg} / \mathrm{ha}$ for coriander and 20-25 kg/ha for fenugreek (Singh et al., 2015). These crops are also sown by using seed cum fertilizer drills and improved implements for sowing and fertilizer application, which are being used in cultivation of other field crops (Alam, 2007). These crops have different physical properties which demand improvisation in furrow opener and metering mechanism. Size, shape and test weight of seeds of these crops throw challenge of seed placement at right geometry and assuring required soil cover. Line sowing offers advantages for intercultural operations such as weeding, hoeing, or spraying therefore mechanized sowing of seed spices is the necessity (Singh and Solanki, 2015). Depth of sowing for seed spices is kept very shallow, 1-3 cm (Malhotra, 2016; Sharma et al., 2012; Sastry and Anandraj, 2013 and
Bhutia et al., 2017).Therefore, furrow openers of commonly used in seed drills or planter are not very well suited for sowing of seed spices (Alam, 2007). Some of the spices seed i.e. cumin, coriander and fenugreek are highly sensitive to germination, if proper depth of sowing is not maintained. Even a small layer of soil over the seed affects the germination. The requirement of sowing such that a very thin covering over the seed is sufficient for germination (Vashishtha, 2005). Therefore furrow opener is very important component of seed drill or planter to ensure proper seed and soil contact as well as proper seed placement depth of these seed spices. Keeping the above points in view, an attempt was made to develop and optimize the furrow opener for planting the seeds of coriander, fenugreek and cumin in sandy loam soil at required depth.

\section{Materials and Methods}

An experiment was conducted in soil bin with three furrow openers which had different tip cutting thickness and tilt angle $(\propto)$ to optimize the furrow opener for planting of coriander, fenugreek and cumin seed. The soil bin experiments were conducted in sandy loam soil at soil bin laboratory of CTAE, MPUAT, Udaipur, Rajasthan. The moisture content of soil during the experiment was maintained between $10-11$ per cent (db.). The bulk density of tilled soil was $1.65 \mathrm{~g} / \mathrm{cm}^{3}$. The optimization of furrow openers for planter was carried out by considering the independent and dependent parameters. Three levels were taken for each independent parameter. An experimental design based on the Response Surface Methodology (RSM) was followed to study the effect of speed of operation $\left(\mathrm{S}_{\mathrm{O}} \mathrm{P}\right)$, tip cutting thickness $\left(\mathrm{T}_{\mathrm{C}} \mathrm{T}\right)$, depth of operation $\left(\mathrm{D}_{\mathrm{O}} \mathrm{P}\right)$ and tilt angle $(\propto)$ on draft and furrow back fill percentage. The design used in this study was a Face Centered Central Composite Design (FCCCD). 


\section{Furrow openers geometries}

The geometries viz.tip cutting thickness (2, 3.5 and $5 \mathrm{~mm})$ and tilt angle $\propto\left(3^{0}, 9^{0}\right.$ and $\left.13^{0}\right)$ were tested at three forward speed (1.5, 2 and $2.5 \mathrm{~km} / \mathrm{h})$ and three depth of operation $(15,25$ and $35 \mathrm{~mm}$ ). Total 20 experimental combination with three replications were conducted during the study. To reduce the effect of shank width on soil throw, thus designed openers had provision to be fit on common shank $(10 \times 10 \mathrm{~mm})$. The position of furrow opener on shank for these three depth were calibrated on hard and plan surface and validated in soil bin from multiple measurements.

\section{Measurement of draft}

The drafts of furrow openers were determined using load cell fixture placed between tool trolley unit and developed planter (Fig. 1). The load cell with load rating of $1.96 \mathrm{kN}$ (F256) was connected to load cell indicator (Monad digitizer).

\section{Measurement of furrow back fills percentage}

The measurement of furrow back fill percentage was followed as mentioned by Barr et al., (2016). The cross section area of furrow opener opened was divided in to two parts i.e. $A_{1}$ and $A_{2}$ (furrow back fill area and dip area). The area $A_{1}$ and $A_{2}$ were represented in fig. 2. The furrow back fill percentage was calculated by using the equation given below.

Furrow back fill percentage $=\frac{A_{1}}{A_{1}+A_{2}} \times 100$

\section{Optimization of furrow opener}

After the soil bin experiments the data were analyzed for optimum condition of dependent parameters. The furrow opener was optimized based on three input variables i.e speed of operation, tip cutting thickness and tilt angle, whose interaction effects were studied as two major output i.e. draft and furrow back fill percentage. The optimum values of the independent variables were obtained using numerical optimization technique using RSM with the help of Design-Expert software.

The experimental data obtained from soil bin study were fitted to a second order polynomial model. It was used to establish a mathematical relationship between the independent and dependent parameters with general form as following.

$$
Y=\beta_{0}+\sum_{i=1}^{k} \beta_{i} X_{i}+\sum \beta_{i i} X_{i}^{2}+\sum_{i} \sum_{j} \beta_{i j} X_{i} X_{j}+\varepsilon
$$

Where, $\mathrm{Y}$ is predicted value of dependent parameter; $\mathrm{k}$ is number of parameters; $\beta_{0}$ is intercept; $\beta_{\mathrm{i}}, \quad \beta_{\mathrm{ii}}$ and $\beta_{\mathrm{ij}}$ are regression coefficients; $X_{i}$ and $X_{j}$ are independent parameters; and $\varepsilon$ is Error (Table 1).

\section{Results and Discussion}

The experiment conducted reveled that speed of operation, tip cutting thickness and depth of operation significantly affected the draft and furrow back fill percentage (Table 2 and Table 3). F-value of 98.90 and 24.56 for effect on draft and furrow back fill percentage, respectively indicated that model was significant.

Coefficient of determination $\left(R^{2}\right)$ were found to be 0.98 and 0.95 for effect of independent parameters on draft and furrow back fill percentage indicated the goodness of the fitted model. Lack of fit was found to be nonsignificant which confirmed the goodness of the model that can predict the value of draft and furrow back fill percentage. 
Table.1 Analysis of variance for effect of $X_{1}, X_{2}$ and $X_{3}$ on draft

\begin{tabular}{|c|c|c|c|c|}
\hline Source & Sum of Squares & df & Mean Square & F Value \\
\hline Model & 9183.57 & 9 & 1020.40 & $98.90 * *$ \\
\hline $\begin{array}{l}\text { Speed of operation, } \mathrm{km} / \mathrm{h} \\
\left(\mathrm{X}_{1}\right)\end{array}$ & 1098.32 & 1 & 1098.32 & $106.45 * *$ \\
\hline $\begin{array}{l}\text { Tip cutting thickness, } \mathrm{mm} \\
\left(\mathrm{X}_{2}\right)\end{array}$ & 4724.77 & 1 & 4724.77 & $457.94 * *$ \\
\hline Depth of operation, $\mathbf{m m}\left(\mathrm{X}_{3}\right)$ & 2768.84 & 1 & 2768.84 & $268.36 * *$ \\
\hline $\mathbf{X}_{1} \mathbf{X}_{2}$ & 4.51 & 1 & 4.51 & NS \\
\hline $\mathbf{X}_{1} \mathbf{X}_{3}$ & 0.77 & 1 & 0.77 & NS \\
\hline $\mathbf{X}_{2} \mathbf{X}_{3}$ & 238.50 & 1 & 238.50 & $23.12 * *$ \\
\hline $\mathbf{X}_{1}^{2}$ & 12.31 & 1 & 12.31 & NS \\
\hline $\mathbf{X}_{2}^{2}$ & 16.40 & 1 & 16.40 & NS \\
\hline $\mathbf{X}_{3}{ }^{2}$ & 69.80 & 1 & 69.80 & $6.76^{*}$ \\
\hline Lack of Fit & 84.80 & 5 & 16.96 & NS \\
\hline
\end{tabular}

Significant at $1 \%$ level of significance, ${ }^{*}$ Significant at $5 \%$ level of significance $\mathrm{NS}=$ Not significant

Table.2 Analysis of variance effect of speed of operation, tip cutting thickness and depth of operation on furrow back fill percentage

\begin{tabular}{|l|c|c|c|c|}
\hline \multicolumn{1}{|c|}{ Source } & Sum of Squares & df & Mean Square & F Value \\
\hline Model & 1029.23 & 9 & 114.36 & $24.56^{* * *}$ \\
\hline Speed of operation, $\mathbf{k m} / \mathbf{h}\left(\mathbf{X}_{\mathbf{1}}\right)$ & 214.04 & 1 & 214.04 & $45.98^{* *}$ \\
\hline Tip cutting thickness, $\mathbf{m m}\left(\mathbf{X}_{\mathbf{2}}\right)$ & 360.31 & 1 & 360.31 & $77.40^{* *}$ \\
\hline Depth of operation, $\mathbf{m m}\left(\mathbf{X}_{\mathbf{3}}\right)$ & 380.46 & 1 & 380.46 & $81.72^{* *}$ \\
\hline $\mathbf{X}_{\mathbf{1}} \mathbf{X}_{\mathbf{2}}$ & 8.85 & 1 & 8.85 & NS \\
\hline $\mathbf{X}_{\mathbf{1}} \mathbf{X}_{\mathbf{3}}$ & 1.85 & 1 & 1.85 & NS \\
\hline $\mathbf{X}_{\mathbf{2}} \mathbf{X}_{\mathbf{3}}$ & 6.57 & 1 & 6.57 & NS \\
\hline $\mathbf{X}_{\mathbf{1}}^{\mathbf{2}}$ & 7.43 & 1 & 7.43 & NS \\
\hline $\mathbf{X}_{\mathbf{2}}^{\mathbf{2}}$ & 50.36 & 1 & 50.36 & $10.82^{* *}$ \\
\hline $\mathbf{X}_{\mathbf{3}}^{\mathbf{2}}$ & 20.73 & 1 & 20.73 & NS \\
\hline Lack of Fit & 34.77 & 5 & 6.95 & NS \\
\hline
\end{tabular}

${ }^{* *}$ Significant at $1 \%$ level of significance, ${ }^{*}$ Significant at $5 \%$ level of significance NS $=$ Not significant 
Table.3 Criteria for optimization and optimized values of independent parameters and corresponding predicted values for dependent parameters

\begin{tabular}{|c|c|c|c|c|c|}
\hline Parameters & Goal & $\begin{array}{l}\text { Lower } \\
\text { Limit }\end{array}$ & $\begin{array}{l}\text { Upper } \\
\text { Limit }\end{array}$ & $\begin{array}{c}\text { Optimized/ } \\
\text { Predicted value }\end{array}$ & $\begin{array}{c}\text { Overall } \\
\text { Desirability }\end{array}$ \\
\hline Speed, (km/h) & In range & 1.5 & 2.5 & 1.5 & \multirow[t]{5}{*}{0.70} \\
\hline Tip cutting thickness, (mm) & In range & 2 & 5 & 3.15 & \\
\hline Depth, $(\mathrm{mm})$ & In range & 15 & 35 & 30.75 & \\
\hline Draft, $(\mathrm{N})$ & Minimize & 63.21 & 160.07 & 92.70 & \\
\hline Furrow back fill, (\%) & Maximize & 28.81 & 62.07 & 52.26 & \\
\hline
\end{tabular}

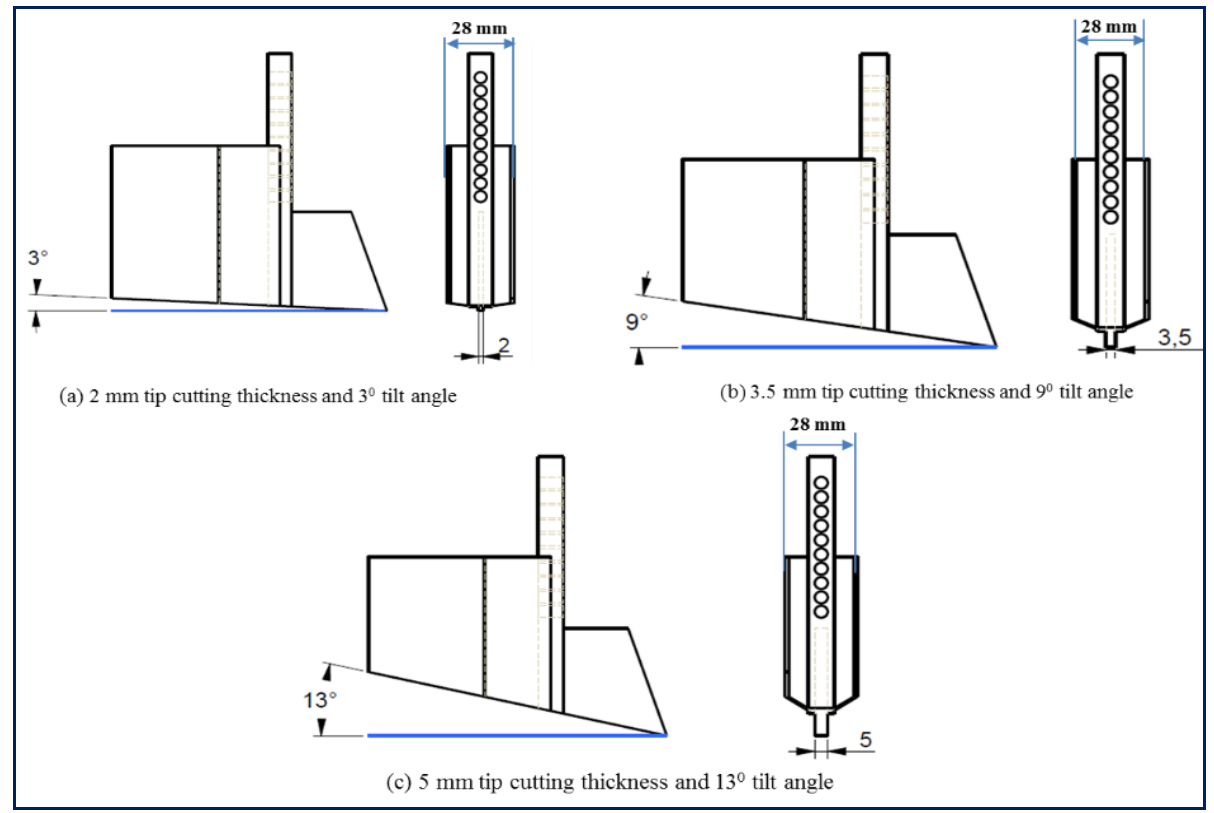

Fig.1 Geometry of Furrow openers F1 (a), F2 (b) and F3 (c)

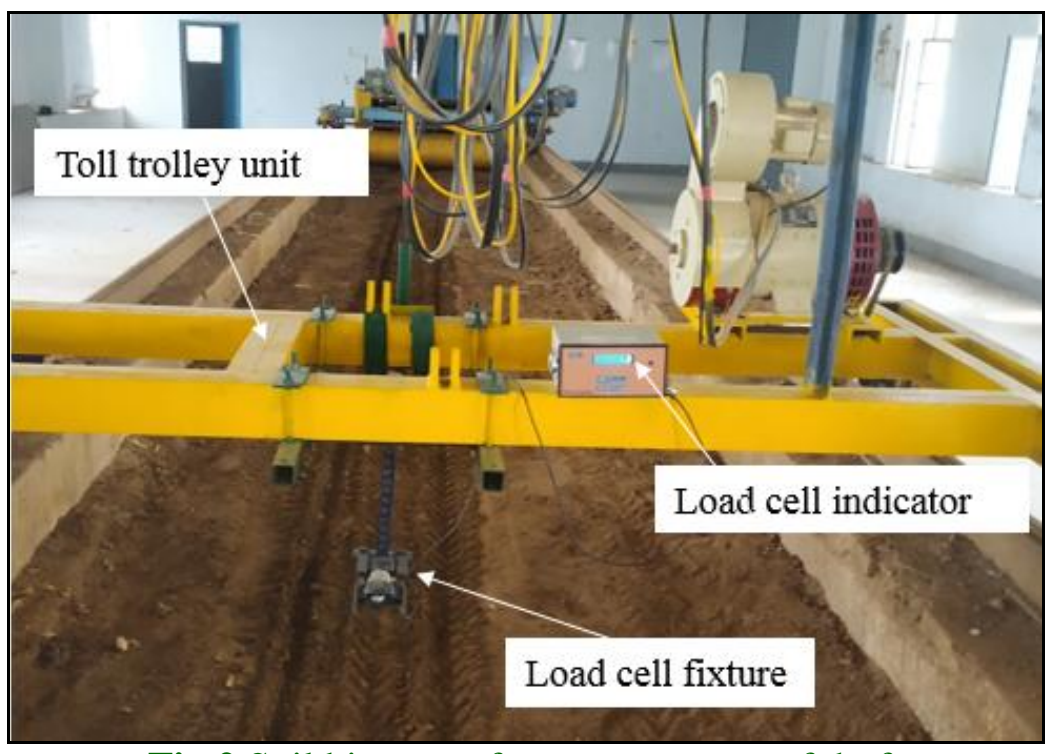

Fig.2 Soil bin setup for measurement of draft 


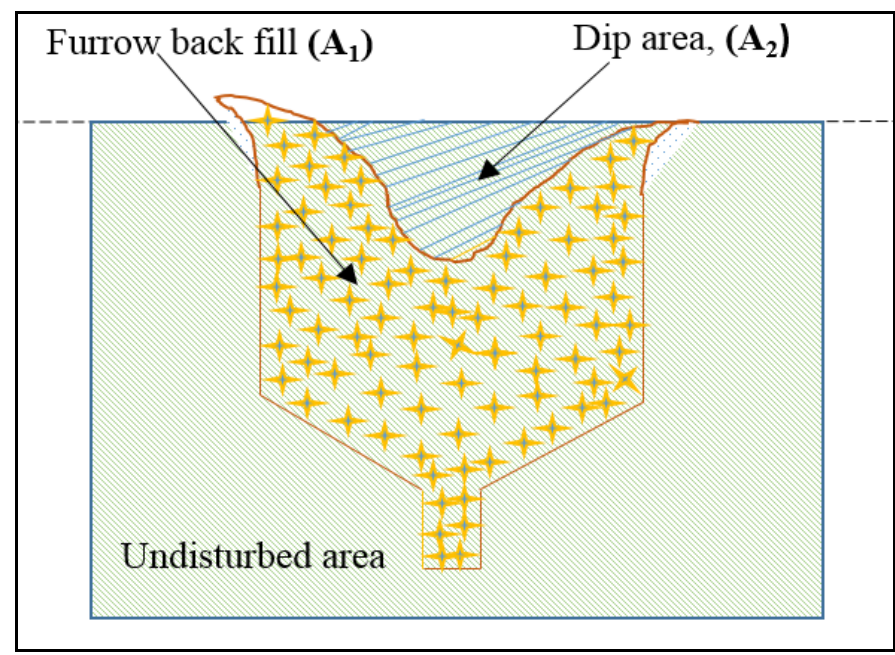

Fig.3 Defining furrow back fill area, dip area and undisturbed area

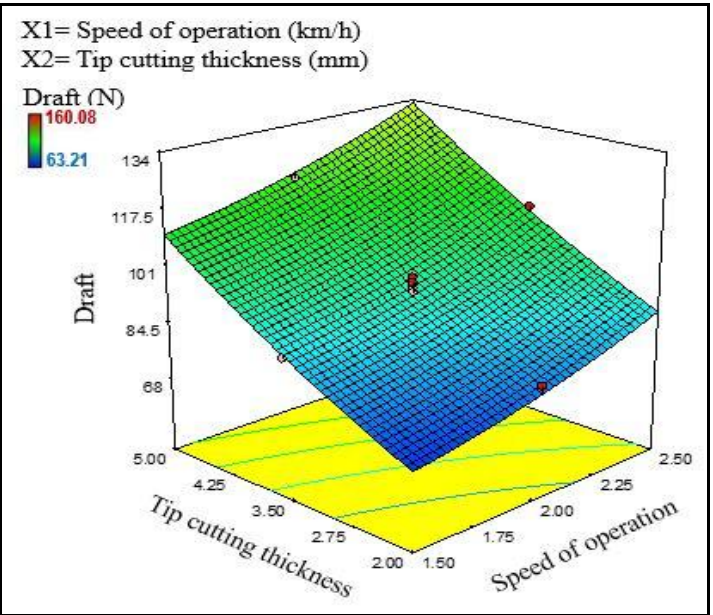

Fig.4 Effect of $\mathrm{T}_{\mathrm{C}} \mathrm{T}$ and $\mathrm{S}_{\mathrm{O}} \mathrm{P}$ on draft

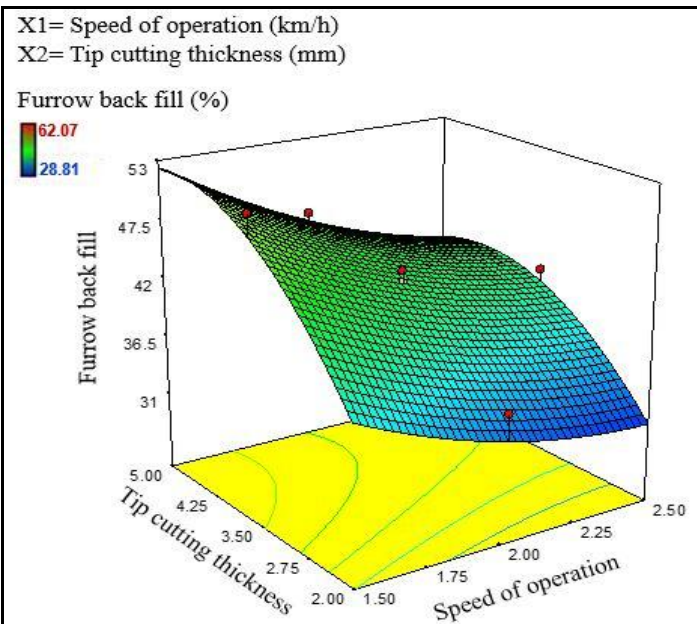

Fig.6 Effect of $\mathrm{T}_{\mathrm{C}} \mathrm{T}$ and $\mathrm{S}_{\mathrm{O}} \mathrm{P}$ on Furrow back fill (\%)

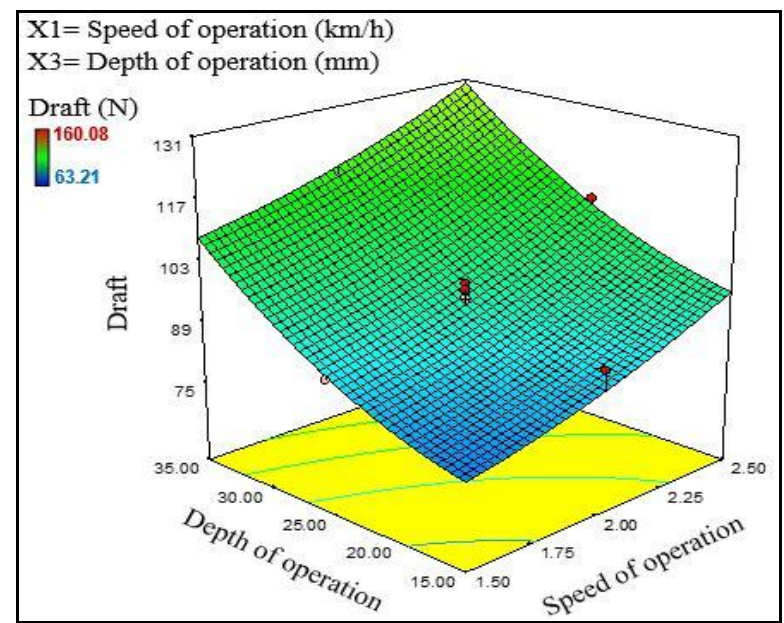

Fig.5 Effect of $\mathrm{D}_{\mathrm{O}} \mathrm{P}$ and $\mathrm{S}_{\mathrm{O}} \mathrm{P}$ on draft

$\mathrm{X} 1=$ Speed of operation $(\mathrm{km} / \mathrm{h})$ $\mathrm{X} 3=$ Depth of operation $(\mathrm{mm})$

Furrow back fill (\%)

62.07

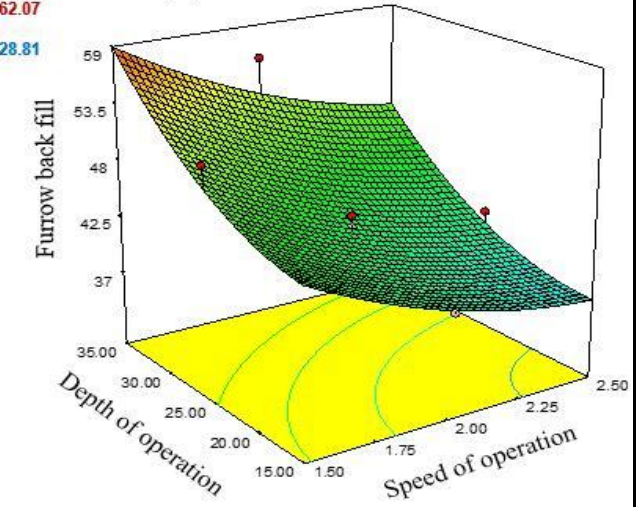

Fig.7 Effect of $\mathrm{D}_{\mathrm{O}} \mathrm{P}$ and $\mathrm{S}_{\mathrm{O}} \mathrm{P}$ on Furrow back fill 
Effect of tip cutting thickness, speed of operation and depth of operation on draft

The result obtained from experiment conducted showed that, effect of speed of operation, tip cutting thickness, and depth of operation were found to be significant on draft (Table 2; fig. 3 and fig. 4). With increase in these parameters draft increased significantly. The interaction effects of X2 X3 were found significant at 5 percent level of significance (Table 2). The draft of furrow openers ranged from $63.21 \mathrm{~N}$ to $160.07 \mathrm{~N}$. The maximum draft was found for $\mathrm{F}_{3}$ furrow opener, this can be attributed to increase in tip cutting thickness and tilt angle $\propto\left(13^{0}\right)$ for $\mathrm{F}_{3}$ furrow opener. The results obtained were in agreement with the study conducted by Barr et al., (2016) and Bertonha et al., (2015).

Effect of tip cutting thickness, speed of operation, tilt angle and depth of operation on furrow back fill percentage

The effect of speed of operation, tip cutting thickness, depth of operation and tilt angle $\propto$ on furrow back fill percentage was found to be significant $(P<0.01)$. With increase in speed of operation the furrow back fill percentage decreased significantly but increased with increase in depth of operation and tilt angle $\propto$ (fig. 5 and fig. 6). These result followed expected trends from previous study conducted in soil bin and field (Hoque et al., 2014; Barr et al., 2016). The furrow back

fills percentage varied from 28.81 to 62.07 percentage. The highest back fill percentage $(62.07 \%)$ was found for $\mathrm{F}_{3}$ furrow opener at $1.5 \mathrm{~km} / \mathrm{h}$ speed and $35 \mathrm{~mm}$ depth of operation.

\section{Optimized values for furrow opener}

All the input parameters were kept within range while the output parameters were either minimized/maximized or kept in range (Table $3)$. The applied independent parameters and the predicted optimum values obtained for the draft and furrow back fill percentage are presented in Table 3. The optimized values of speed of operation, tip cutting thickness, and depth of operation obtained were $1.5 \mathrm{~km} / \mathrm{h}$, $3.15 \mathrm{~mm}$ and $30.75 \mathrm{~mm}$, respectively. The predicted values of draft and furrow back fill percentage obtained were $92.70 \mathrm{~N}$ and 52.26 respectively. The overall desirability of all parameters was found to be 0.70 . The optimized and predicted values of parameters matched with the $F_{2}$ furrow opener.

The effects of three operating speeds $(1.5,2$ and $2.5 \mathrm{~km} / \mathrm{h}$ ), tip cutting thickness $(2,3.5$ and $5 \mathrm{~mm})$, depth of operation $(15,25$ and 35 $\mathrm{mm})$ and tilt angle $\propto\left(3^{0}, 9^{0}\right.$ and $\left.13^{0}\right)$ on draft requirement and furrow back fill percentage were evaluated for optimization of furrow opener for the sowing of selected seed spices. The optimized and predicted value of parameters matched with the $F_{2}$ furrow opener. The furrow opener $\mathrm{F}_{2}$ maintained better furrow backfill than the $F_{1}$ and $F_{3}$. However, $\mathrm{F}_{3}$ had increased draft with increase in speed and depth of operation.

The combination of the speed of operation, tip cutting thickness depth of operation and tilt angle $(\propto)$ of the $F_{2}$ furrow opener resulted in optimum values of draft and furrow back fill percentage. The conducted experiment was helped to select the best furrow opener for selected seed spices on the basis of less draft requirement and higher back fill percentage at optimum conditions.

\section{Acknowledgment}

The authors gratefully acknowledge the College of Technology And Engineering, MPUAT, Udaipur, Rajasthan for support and providing necessary facility to conduct this research work. 


\section{References}

Alam, A. 2007. Possibilities of mechanization in seed spices. In: Malhotra, S. K. and Vashishtha, B. B. (Eds.), Proceedings of National Seminar on "Production, Development, Quality and Export of Seed Spices - Issues and Strategies" February 2-3, NRCSS, Ajmer,pp. 1-11.

Anonymous, 2007. NRCSS-Perspective Plan 2025. National Research Centre on Seed Spices Ajmer, Rajasthan.

Barr, J. B., Desbiolles, J. M.A., Fielke, J.M. 2016. Minimizing soil disturbance and reaction forces for high speed sowing using bentleg furrow openers. Biosystems engineering, 151(64).

Bertonha, R.S., Furlani, C.E.A., Silva, V.F. A. and Chioderoli, C.A. 2015. Fuel demand as a function of furrow opener and soil conditions in no-tillage system. African Journal of Agricultural Research. Vol. 10 (11), pp. 1266-1272.

Bhatt, Y. C. 2013. Tractor Operated Seed Spices Planter. In: Mehta, C. R. (Ed.), Success story, AICRP on Farm Implements and Machines, ICARCIAE, Bhopal, pp 1-8.

Bhutia,K.C., Bhutia, S.O., Chatterjee, R. and Chattopadhyay, N.2017. Growth, Phenology and Yield of Fenugreek (Trigonella foenum-graecum L.) as Influenced by Date of Sowing. Int.J. Curr. Microbiol. App. Sci. 6(10): 18101817.

Hoque, M. A., Hossain M. M., Uddin ATMZ, Krupnik, T.J., Pandit, D.B., Yasmin, S. and Gathala M.K. (2014). Furrow openers design can improve seed placement and emergence in strip tillage. In: Regional Conference on Conservation Agriculture for Smallholders in Asia and Africa. December, 7-11, Mymensigh, Bangladesh.

Malhotra, S. K. 2016. Recent advances in seed spices research - A review. Annals of Plant and Soil Research. 18(4): 300308.

Sastry, E. V. D. and Anandaraj, M. 2013.Cumin, Fennel and Fenugreek. Soils, plant growth and crop production (PDF). Encyclopedia of Life Support Systems (EOLSS). Retrieved 29 November.

Sharma, M. M. Sand Sharma R. K. Coriander. 2012. Handbook of herbs and spices. In: Peter, K. V. (Ed.), Woodhead Publishing, 1518 Philadelphia, USA. pp 216-249.

Singh, B. Mehta, R. S., Lal, G., Kankani, R. K., singh, R., Dubey, P. N., Mishra, B. K. and Verma, A. K. 2015. Production technology ofqualitied seed spices crops. AICRP-NRCSS, Ajmer, Rajasthan, publication no. Extn. Leaflet-1/2015.

Singh, B., and Solanki, R. 2015.Status of seed spices research and development in India. Indian Journal of Agricultural Sciences. 85(2): 151-6.

Vashishtha, B.B., 2005. Mechanization in seed spices crop. In: Singh, P., Mathur, A. N., Batt, Y. C., Mehta, A. K. and Pandey, M. M. (Eds.), Mechanization in seed, spices and medicinal plants. Himanshu Publication, Udaipur. pp. 168-170.

\section{How to cite this article:}

Mukesh Kumar Singh, G. S. Tiwari, S. M. Mathur, Ajay Kumar Sharma and Rathod, R. K. 2020. Development and Optimization of Furrow Opener for Planting of Seed Spices. Int.J.Curr.Microbiol.App.Sci. 9(05): 2002-2009. doi: https://doi.org/10.20546/ijcmas.2020.905.226 